\title{
Somatostatin Receptor Subtype 4 Couples to the M-Current to Regulate Seizures
}

\author{
Cuie Qiu, ${ }^{1}$ Thomas Zeyda, ${ }^{2}$ Brian Johnson, ${ }^{1}$ Ute Hochgeschwender, ${ }^{3}$ Luis de Lecea, ${ }^{4}$ and Melanie K. Tallent ${ }^{1}$ \\ ${ }^{1}$ Department of Pharmacology and Physiology, Drexel University College of Medicine, Philadelphia, Pennsylvania 19348, ${ }^{2}$ John A. Burns School of \\ Medicine, Honolulu, Hawaii 96813, ${ }^{3}$ Oklahoma Medical Research Foundation, Oklahoma City, Oklahoma 73104, and ${ }^{4}$ Department of Psychiatry and \\ Behavioral Sciences, Stanford University, Palo Alto, California 94304
}

The $\mathrm{K}^{+} \mathrm{M}$-current $\left(I_{\mathrm{M}}, \mathrm{Kv} 7\right)$ is an important regulator of cortical excitability, and mutations in these channels cause a seizure disorder in humans. The neuropeptide somatostatin (SST), which has antiepileptic properties, augments $I_{\mathrm{M}}$ in hippocampal CA1 pyramidal neurons. We used SST receptor knock-out mice and subtype-selective ligands to investigate the receptor subtype that couples to $I_{\mathrm{M}}$ and mediates the antiepileptic effects of SST. Using pentylenetetrazole as a chemoconvulsant, $S S T_{2}, S S T_{3}$, and $S S T_{4}$ receptor knock-out mice all had shorter latencies to different seizure stages and increased seizure severity when compared with wild-type mice. However, the most robust differences were observed in the $S S T_{4}$ knock-outs. When seizures were induced by systemic injection of kainate, only $S S T_{4}$ knock-outs showed an increase in seizure sensitivity. We next examined the action of SST and subtype-selective SST agonists on electrophysiological parameters in hippocampal slices of wild-type and receptor knock-out mice. $\mathrm{SST}_{2}$ and $\mathrm{SST}_{4}$ appear to mediate the majority of SST inhibition of epileptiform activity in CA1. SST lacked presynaptic effects in mouse CA1, in contrast to our previous findings in rat. SST increased $I_{\mathrm{M}}$ in CA1 pyramidal neurons of wild-type and $S S T_{2}$ knock-out mice, but not $S S T_{4}$ knock-out mice. Using M-channel blockers, we found that $\mathrm{SST}_{4}$ coupling to M-channels is critical to its inhibition of epileptiform activity. This is the first demonstration of an endogenous enhancer of $I_{\mathrm{M}}$ that is important in controlling seizure activity. $\mathrm{SST}_{4}$ receptors could therefore be an important novel target for developing new antiepileptic and antiepileptogenic drugs.

Key words: somatostatin; Kv7 channels; KCNQ; epilepsy; knock-out mice; electrophysiology

\section{Introduction}

The neuropeptide somatostatin (SST) is an important regulator of hippocampal excitability. SST has strong antiseizure actions in many rodent models (Vezzani and Hoyer, 1999), with the hippocampus indicated as the major site of action (Mazarati and Telegdy, 1992). At the cellular level, SST has inhibitory actions in rat CA1 hippocampus, including inhibition of excitatory neurotransmission (Boehm and Betz, 1997; Tallent and Siggins, 1997), and augmentation of two distinct $\mathrm{K}^{+}$current, the voltagesensitive M-current $\left(I_{\mathrm{M})}\right.$ (Moore et al., 1988) and a voltageinsensitive leak current (Schweitzer et al., 1998).

The Kv7 (KCNQ) family of $\mathrm{K}^{+}$channels comprise M-channels. Mutations in two members of this family, Kv7.2 and Kv7.3, cause the epilepsy syndrome benign familial neonatal convulsions (Biervert et al., 1998; Charlier et al., 1998; Singh et al., 1998). Patients with this disorder develop seizures shortly after

Received 0ct. 15, 2007; revised Feb. 18, 2008; accepted Feb. 22, 2008.

This work was supported by National Institutes of Health Grants NS38633 and NS048241 to M.K.T. and MH58543 to L.d.L., and an Epilepsy Foundation predoctoral fellowship to C.Q. We thank Ms. Emily Einstein and Ms. Carlyn Patterson for excellent technical assistance. We would also like to thank the following people for generously providing compounds: Dr. Daniel Hoyer and Dr. Herbert Schmid (Novartis) for octreotide, ACQ090, and SRA880; Dr. M. Engstrom (Juvantia Pharmaceuticals) for J-2156; and Dr. Susan Rohrer (Merck) for L-796,778 and L-803,087. Wealso thank Dr. James Schaeffer (Merck) for providing the SST, knock-out mice.

Correspondence should be addressed to Melanie K. Tallent, Department of Pharmacology and Physiology, Drexel University College of Medicine, Philadelphia, PA 19102. E-mail: tallent@drexel.edu.

DOI:10.1523/JNEUROSCI.4679-07.2008

Copyright $\odot 2008$ Society for Neuroscience $\quad$ 0270-6474/08/283567-10\$15.00/0 birth that spontaneously remit within a few months. However, these patients also have a tenfold higher likelihood of developing temporal lobe epilepsy as adults (Singh et al., 2003), suggesting these channels remain important throughout the lifespan. We showed previously that $I_{\mathrm{M}}$ is critical in preventing the transition from preseizure interictal epileptiform bursting to ictal seizurelike events in hippocampal slices from both adult and immature rats (Qiu et al., 2007). Furthermore, the drug retigabine, that robustly increases $I_{\mathrm{M}}$, has potent antiepileptic actions in pharmacoresistant animal models (Armand et al., 1999, 2000). After successful completion of Phase II clinical trials (Porter et al., 2007b), retigabine is currently in Phase III clinical trials for treatment of refractory partial seizures (Porter et al., 2007a,b).

The contribution of $I_{\mathrm{M}}$ to the antiepileptic actions of SST is unknown. The neuropeptide nociceptin/OFQ also couples to $I_{\mathrm{M}}$ in CA1 and CA3 hippocampus, however, its antiepileptic actions, at least in vitro, appear to be independent of this current (Tallent et al., 2001). Furthermore, whether endogenous regulators of M-channels would have similar antiepileptic actions as retigabine has not been determined. Targeting an upstream regulator of M-channels could be advantageous, because Kv7 channels are widely distributed throughout the brain and periphery, increasing the possibility of unwanted side effects.

The SST family of receptors has 5 members, $\mathrm{SST}_{1}-\mathrm{SST}_{5}$, all of which are $\mathrm{G}_{\mathrm{i}} / \mathrm{G}_{\mathrm{o}}$-coupled receptors. $\mathrm{SST}_{1}-\mathrm{SST}_{4}$ are present in the brain, and $\mathrm{SST}_{2}, \mathrm{SST}_{3}$, and $\mathrm{SST}_{4}$ are expressed in cortex and hip- 
pocampus (Dournaud et al., 1996; Handel et al., 1999; Schreff et al., 2000), although expression of SST ${ }_{1}$ in forebrain is still somewhat controversial (Hervieu and Emson, 1998; Schulz et al., 2000). The receptor subtype mediating inhibitory effects of SST in hippocampus is unknown. The goal of this study was to address these deficiencies using $S S T_{2}, S S T_{3}$, and $S S T_{4}$ knock-out (KO) mice and selective pharmacological tools. We show here that $\mathrm{SST}_{4}$ is the major player in mediating the antiepileptic actions of SST, although $\mathrm{SST}_{2}$ and $\mathrm{SST}_{3}$ also contribute. Furthermore, we demonstrate that the major mechanism through which $\mathrm{SST}_{4}$ acts is augmentation of $I_{\mathrm{M}}$. Thus, targeting $\mathrm{SST}_{4}$, which has limited distribution in the brain, could lead to development of novel antiepileptic drugs.

\section{Materials and Methods}

Generation of $\mathrm{SST}_{3}$ and $\mathrm{SST}_{4}$ knock-out mice. We isolated genomic DNA clones containing the coding region for $S S T_{3}$ and $S S T_{4}$ from a $129 \mathrm{~Sv}$ genomic phage library (Lambda Fix; Stratagene, La Jolla, CA) (Schwabe et al., 1996). Targeting vectors were assembled around a neomycin cassette (pAB5) (Zeyda et al., 2001) consisting of the SV40 enhancer, the tk promoter, and the coding region for neomycin. For the $S_{S T} T_{3}$ targeting vector, we deleted a $427 \mathrm{bp}$ SacI-SalI fragment from the middle of the coding region and replaced it with the neomycin cassette, flanked $5^{\prime}$ by a $1.7 \mathrm{~kb}$ SacI fragment, and 3' by a $6.5 \mathrm{~kb}$ SalI-BglII fragment (see Fig. $1 A$ ). For the $\mathrm{SST}_{4}$ targeting vector a $592 \mathrm{bp} \mathrm{SacI-HincII}$ fragment covering most of the coding region for $S_{S T}$ was deleted and replaced by the neo cassette, flanked $5^{\prime}$ by a $6.7 \mathrm{~kb}$ SacI fragment and 3' by a $1.1 \mathrm{~kb}$ HincIIEcoRI fragment (see Fig. $1 B$ ).

We introduced the targeting plasmids by electroporation into $\mathrm{J} 1 \mathrm{em}-$ bryonic stem cells as described previously (Li et al., 1992; Zeyda et al., 2001). Colonies were screened for homologous integration by PCR, using primers $5^{\prime}$ of the start of the targeting vector (F3: $5^{\prime}$ CCAGATTCGCTAGACCCAGCTCAA) and from the neo cassette (R3: 5' TCCACACCCTAACTGACACAC) for $S T_{3}$, and $3^{\prime}$ of the start of the targeting vector (R4: 5' CCTTCCCCCTCATAGCATAGCTCG) and from the neo cassette (F4: 5' ATCCAGGAAACCAGCAGCGGCTAT) for $S S T_{4}$.

Clones with the expected rearrangement at the targeted locus were injected into C57BL/6J blastocysts. We mated chimeric males transmitting the mutation through the germline to $129 \mathrm{~Sv}$ wild-type females (129SvEv-Tac; Taconic, Germantown, NY) to keep the mutation in an isogenic background. Genotyping was done by PCR on tail DNA as described (Zeyda et al., 2001). Presence or absence of the mutant and wildtype alleles was determined using the following PCR primers: wild-typeF3, ctacacggccgcactgggcttctt; mutant-F3, ATCCAGGAAACCAGCA GCGGCTAT; R3, TTCCATCACTGGACCCTGGTACCA; wild-type F4, cactagg ctcgtgctaatggtggt; mutant-F4, ATCCAGGAAACCAGCAGCGGCTAT; and R4, GCTTGCAGCCAGGTTCTGCTTGCA.

We analyzed DNA from wild-type and mutant littermates by Southern blotting for the expected rearrangement at the mutated locus(Fig. 1C,D). PCR analysis of reverse-transcribed mRNA from whole brain of wildtype and homozygous mutant mice was performed as described previously (Sharifi et al., 2001).

Animal use was in accordance with National Institutes of Health policy and was approved by the Drexel University College of Medicine Institutional Animal Care and Use Committee. Male and female mice were 5-8 weeks old for in vitro studies and 6-10 weeks old for in vivo studies. We used four strains of mice in this study: somatostatin receptor subtype 2 $\left(S S T_{2}\right)$ knock-outs, $S S T_{3}$ knock-outs, $S S T_{4}$ knock-outs, and wild-type mice. SST 2 knock-out mice were provided by Merck Pharmaceuticals (Whitehouse Station, NJ) and have been characterized phenotypically (Viollet et al., 2000; Dutar et al., 2002). We did limited studies on $S S T_{2} /$ $\mathrm{SST}_{4}$ double knock-outs, which were bigenic crosses between the $\mathrm{SST}_{2}$ and $\mathrm{SST}_{4}$ knock-outs. SST receptor knock-out mice were bred in-house and C57BL/6J wild-type mice were purchased from Jackson Laboratories (Bar Harbor, ME). For in vivo seizure studies and electrophysiological studies, we backcrossed receptor knock-out mice at least 10 generations to C57BL/6J to increase genetic homogeneity (Silva et al., 1997).
Seizure models. Pentylenetetrazole (PTZ) was dissolved in saline and injected intraperitoneally. The dosage was $50 \mathrm{mg} / \mathrm{kg}$. Animals were observed and videotaped for $30 \mathrm{~min}$ after injection. We scaled seizure behavior as follows (modified from Racine, 1972): stage 1, hypoactivity; stage 2, tail extension or limb jerk; stage 3, whole-body clonus; stage 4, rolling, running, jumping, and tonic-clonic. The experimenter was blind to the phenotype of the mice.

In the second seizure model, we dissolved kainic acid in saline, adjusted $\mathrm{pH}$ to 7.2, and injected subcutaneously. Dosage required to reliably elicit seizures in wild-type mice was established for each group of mice, after which wild-type and knock-out mice were tested side by side. Dosage was $20 \mathrm{mg} / \mathrm{kg}$ for wild-type and $S S T_{3}$ and $S S T_{4}$ knock-out mice, and $30 \mathrm{mg} / \mathrm{kg}$ for $S S T_{2}$ knock-out mice, which were tested at a later time. We observed and videotaped mice for $120 \mathrm{~min}$ after injection. Seizure behavior was scaled as the following: 1 , hypoactivity; 2 , myoclonic jerks of head and neck, forelimb, or hindlimb clonus; 3 , partial rearing and rearing; 4, rearing and falling; 5, generalized tonic-clonic convulsions with loss of postural tone, rolling, and jumping. In both models, animals did not always progress sequentially through each seizure stage, but could skip stages.

In vitro electrophysiology. We made hippocampal slices from mice as described previously (Tallent et al., 2001). Briefly, mice were anesthetized with halothane $(4 \%)$, decapitated and the brains rapidly removed. We cut transverse hippocampal slices $(350-400 \mu \mathrm{M})$ on a vibraslicer (Vibrotome, St. Louis, MO) or tissue chopper (Vibratome) and placed them in artificial CSF (ACSF), gassed with $95 \% \mathrm{O}_{2} / 5 \% \mathrm{CO}_{2}$ (carbogen), of the following composition (in mM): $130 \mathrm{NaCl}, 3.5 \mathrm{KCl}, 1.25 \mathrm{NaH}_{2} \mathrm{PO}_{4}, 1.5$ $\mathrm{MgSO}_{4}, 2 \mathrm{CaCl}_{2}, 24 \mathrm{NaHCO} 3$, and 10 glucose. After 20 min of incubation with their upper surfaces exposed to warmed, humidified carbogen, the slices were submerged and superfused with $\operatorname{ACSF}\left(31^{\circ} \mathrm{C}\right)$ at a constant rate $(3-4 \mathrm{ml} / \mathrm{min}$ ) for the remainder of the experiment. The inner chamber had a total volume of $1 \mathrm{ml}$; at the superfusion rates used, $90 \%$ replacement of the chamber solution could be obtained within 1-1.5 min. We added drugs and peptides to the bath from stock solutions at known concentrations. $\mathrm{Mg}^{2+}$-free ACSF was the same composition as above except no $\mathrm{MgSO}_{4}$ was added and $1.0 \mathrm{~mm}$ of $\mathrm{KCl}$ was used. SST-14 (1-4 $\mu \mathrm{M})$, octreotide $(0.5-1 \mu \mathrm{M}), \mathrm{J}-2156$ [(1'S,2S)-4-amino- $N$-(1'-carbamoyl2'-penylethyl)-2-(4"-methyl-1"-naphthalenesulfonylamino)butanamide] $(0.5-1 \mu \mathrm{M})$, and ACQ090 $(1 \mu \mathrm{M})$ were all aliquotted in DMSO, to keep the vehicle consistent between all of the drugs, and added to the bath at 1:1000 dilution, so that the final concentration of DMSO was $0.1 \%$. Vehicle alone had no affect on burst or membrane characteristics.

Extracellular recording. We recorded extracellular epileptiform bursts by conventional means in the CA1 pyramidal layer using glass extracellular pipettes (1-3 $\mathrm{M} \Omega$ tip resistance when filled with $3 \mathrm{M} \mathrm{NaCl}$ ) and a Molecular Devices (Union City, CA) Axoclamp 2B or Multiclamp amplifier (Tallent and Siggins, 1997). Recordings were filtered at $3-10 \mathrm{kHz}$, digitized, and analyzed using pClamp software (Molecular Devices). For recording spontaneous extracellular bursts, we superfused $\mathrm{Mg}^{2+}$-free ACSF until a stable burst rate was achieved, usually $<30 \mathrm{~min}$. Bursting events were acquired via computer and continuously monitored using Axoscope (Molecular Devices). We measured bursting over a 1-2 min period to calculate frequencies, and used as the control rate the period immediately before the beginning of drug superfusion. We calculated maximal drug effects (change in burst rate), which occurred 5-7 min after beginning superfusion for all drugs tested. All drug effects were reversible such that after washout burst rate returned to $93-100 \%$ of control values (data not shown).

Intracellular recording. We used voltage-clamp techniques with sharp intracellular micropipettes $(3 \mathrm{M} \mathrm{KCl}, 50-80 \mathrm{M} \Omega$ ) as described previously (Tallent and Siggins, 1997; Tallent et al., 2001) to record $I_{\mathrm{M}}$. TTX (1 $\left.\mu \mathrm{M}\right)$ was used to block sodium channels during recordings. We recorded from CA1 pyramidal neurons; after stabilization in current-clamp, discontinuous voltage clamp recordings were made using an Axoclamp-2B amplifier (Molecular Devices) and stored on a PC for data analysis using pClamp software (Molecular Devices). Neurons were held near $-40 \mathrm{mV}$ and hyperpolarizing $1 \mathrm{~s}$ voltage steps were applied to measure M-current deactivation. Deactivation kinetics and amplitudes were analyzed using a single-exponential fit of the region of the current spanning the two ca- 
pacitance transients. SST effects were measured by subtracting control current traces from currents recorded in the presence of the peptide, to obtain the net SST-induced current.

We recorded EPSCs in CA1 pyramidal neurons using whole-cell patch clamp and visualized neurons using infrared microscopy. EPSCs were evoked by orthodromic stimulation $(0.05$ ms stimulus duration; $0.1 \mathrm{~Hz}$ frequency) of Schaeffer collaterals with a bipolar tungsten electrode placed in the stratum radiatum. We superfused bicuculline $(30 \mu \mathrm{M})$ to block $\mathrm{GABA}_{\mathrm{A}}$ receptors to isolate EPSCs. Trials were recorded on a computer and continuously monitored with Axoscope software.

Drugs. SST was from Bachem (Bubendorf, Switzerland). Octreotide, ACQ090, SRA880 $[(3 R, 4 \mathrm{a} R, 10 \mathrm{a} R)-1,2,3,4,4 \mathrm{a}, 5,10,10 \mathrm{a}$-octahydro-6methoxy-1-methyl-benz(g)quinoline-3-carboxylic-acid-4-(4-nitrophenyl)-piperazine-amide, hydrogen malonate] (Novartis, Basel, Switzerland), J-2156 (Juvantia Pharmaceuticals, Turku, Finland), and L-796,778 and L-803,087 (Merck Pharmaceuticals) were gifts. All other chemicals were from Sigma (St. Louis, MO). We chose drug concentrations based on receptor affinity profiles (Rohrer et al., 1998; Ramirez et al., 2002) and previous brain slice studies (Cammalleri et al., 2004; Meis et al., 2005).

Statistics. We performed statistical analysis using two-factor ANOVA with or without replication, Student's $t$ test (paired for within group and unpaired for between group comparison), or $\chi^{2}$, as indicated, using Microsoft (Redmond, WA) Excel or SPSS. Data are reported as mean \pm SEM and considered statistically significant at $p<0.05$.

\section{Results}

Generation of $S S T_{3}$ and $S S T_{4}$ knock-out mice

The generation of $S S T_{3}$ and $S S T_{4}$ knock-out mice are detailed in Figure 1. SST receptor genes are intronless genes. Integration of a selection cassette into the coding region disrupts the processing of mRNA and the assembly of the receptor protein. The targeting vectors for $S S T_{3}$ carry a 427 bp and 592 bp deletion, respectively, in the coding region (Fig. $1 A$ ). We mated chimeric mice transmitting the mutated alleles through the germline to $129 / \mathrm{Sv}$ wildtype mice, resulting in the generation of knock-out strains 129/

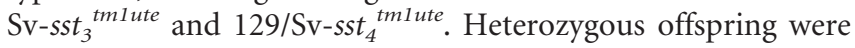
mated to generate homozygous null mutant mice. Southern blot analyses of DNA from wild-type and mutant littermates show the expected rearrangements for the mutant locus (Fig. 1C). An XbaI digest probed with a SacI-XbaI fragment shows the absence of a $6.5 \mathrm{~kb}$ wild-type fragment and the presence of a $7.7 \mathrm{~kb}$ fragment in the $s s t_{3}$ mutant because of the insertion of the neo cassette (Fig. 1C). A HindIII digest probed with a HincII fragment reveals the absence of the $6.7 \mathrm{~kb}$ wild-type fragment and the presence of a 3.8 $\mathrm{kb}$ fragment in the $\mathrm{SST}_{4}$ mutant because of the additional HindIII site from the neo cassette (Fig. 1D). We performed PCR analysis of reverse-transcribed mRNA from whole brain of wild-type and $S_{S} T_{3}$ and $S S T_{4}$ homozygous mutant mice as described previously (Sharifi et al., 2001) and showed the absence of the respective mRNA in the mutants (data not shown).

Mutant mice were born at the frequency expected for a recessive mutation. Mice lacking $S S T_{3}$ or $S S T_{4}$ are viable, appear healthy, and are fertile.

\section{SST receptor knock-out mice had shorter latencies and developed more severe seizures in PTZ seizure model} In the PTZ model, wild-type $(n=26), S S T_{2}(n=15), S S T_{3}(n=$ $23)$, and $\operatorname{SST}_{4}(n=23)$ knock-out mice almost all exhibited stage 1 and stage 2 seizures, with no difference between the groups in the proportion that reached these mild seizures stages $(p>0.05$, $\chi^{2}$ ) (for a summary of these results, see Table 1). However, significantly more $S S T_{3}$ and $S S T_{4}$ knock-out mice than wild-type mice progressed to the more severe seizures (i.e., stage 3 and stage $4, p<0.05)$. For wild-type mice, 48 and $33 \%$ developed stage 3
A

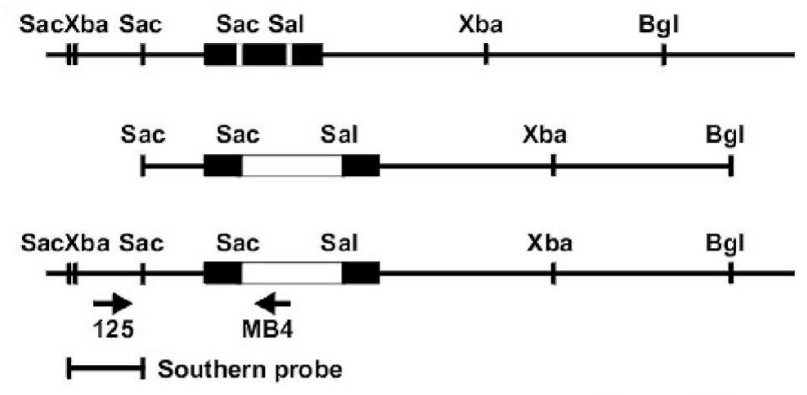

wildtype allele

mutant allele

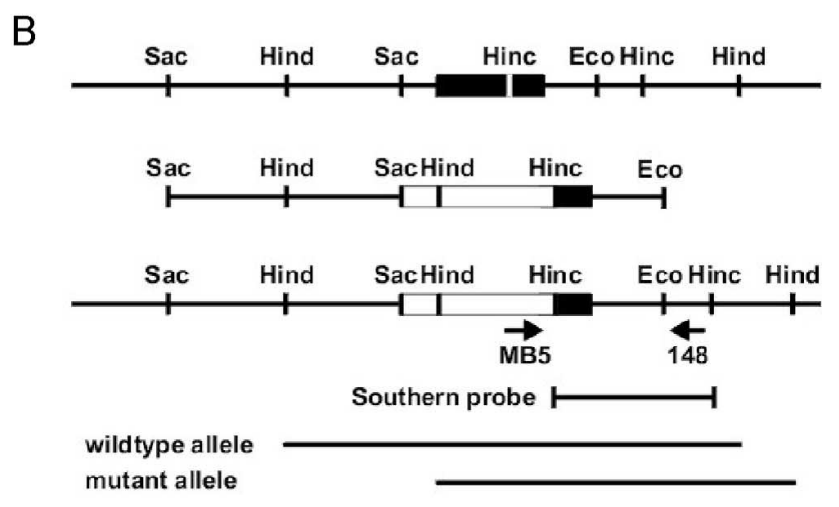

C

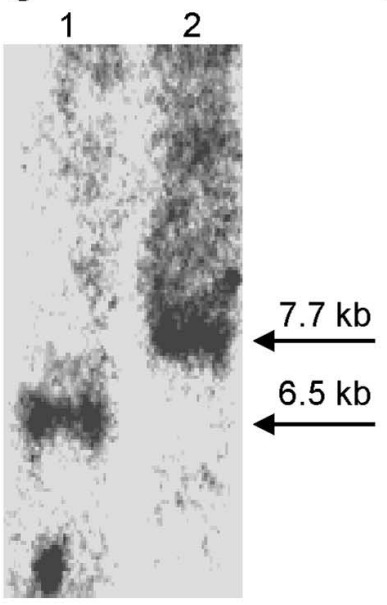

D

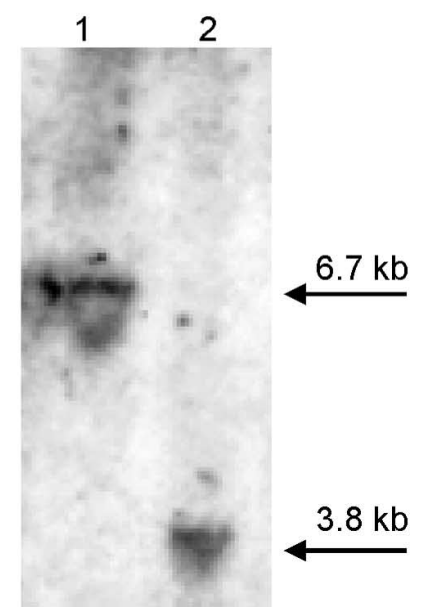

Figure 1. Targeted disruption of the murine $\mathrm{SST}_{3}$ and $\mathrm{SST}_{4}$ genes. A, Targeting strategy for disruption of the $\mathrm{SST}_{3}$ gene. $\mathrm{A} 427 \mathrm{bp}$ Sacl-Sall fragment from the middle of the coding region for $S S T_{3}$ is deleted and replaced by a neo cassette (white box). The neo cassette is flanked $5^{\prime}$ by $1.7 \mathrm{~kb}$ and $3^{\prime}$ by $6.5 \mathrm{~kb}$ of genomic sequence from the SST 3 locus. $\boldsymbol{B}$, A $592 \mathrm{bp}$ Sacl-Hincll fragment covering most of the coding region for $\mathrm{SST}_{4}$ is deleted and replaced by a neo cassette (white box). The neo cassette is flanked $5^{\prime}$ by $6.7 \mathrm{~kb}$ and $3^{\prime}$ by a $1.1 \mathrm{~kb}$ of genomic sequence from the $\mathrm{SST}_{4}$ locus. C, Southern blot analysis of mouse tail DNA from wild-type (1) and $\mathrm{SST}_{3} \mathrm{KO}$ mice (2). DNA was digested with $X b a l$ and subjected to hybridization using a genomic probe (Xbal-Sacl fragment). The expected increase of fragment size in the mutant (from 6.5 to $7.7 \mathrm{~kb}$ ) is depicted schematically and shown in the autoradiograph. $D$, Southern blot analysis of mouse tail DNA from wild-type (1) and SST ${ }_{4} \mathrm{KO}$ mice (1). DNA was digested with Hindlll and subjected to hybridization using a genomic probe (Hincll fragment). The expected decrease of fragment size in the mutant (from 6.7 to $3.8 \mathrm{~kb}$ ) is depicted schematically and shown in the autoradiograph. MB4, 5' TCCACACCCTAACTGACACAC; MB5, 5' ATCCAGGAAACCAGCAGCGGCTAT.

and stage 4 seizures, respectively. For $S S T_{4}$ knock-outs, 100 and $87 \%$ developed stage 3 and stage 4 seizures, whereas 89 and $67 \%$ of $S_{S T}$ knock-outs developed stage 3 and 4 seizures, respectively. In contrast, there was no significant difference between wild-type 
Table 1. PTZ-induced seizure stages in SST receptor knock-out mice

\begin{tabular}{lcccc}
\hline & Wild type & SST $_{2} \mathrm{KO}$ & $\mathrm{SST}_{3} \mathrm{KO}$ & $\mathrm{SST}_{4} \mathrm{KO}$ \\
\hline Stage 1 & $89 \%$ & $100 \%$ & $94 \%$ & $100 \%$ \\
Stage 2 & $81 \%$ & $89 \%$ & $94 \%$ & $96 \%$ \\
Stage 3 & $48 \%$ & $78 \%$ & $89 \%^{*}$ & $100 \%^{*}$ \\
Stage 4 & $33 \%$ & $56 \%$ & $67 \%^{*}$ & $87 \%^{*}$ \\
Death & $0 \%$ & $0 \%$ & $0 \%$ & $17 \%^{*}$ \\
\hline
\end{tabular}

The percentage of mice from each strain that exhibited each seizures stage is shown. Asterisks indicate significant difference from wild type $\left(p<0.05 ; \chi^{2}\right)$.

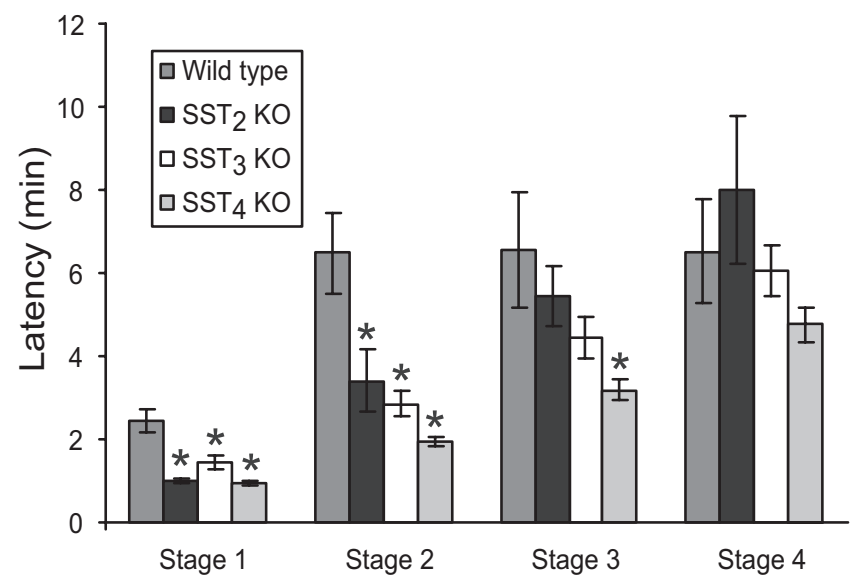

Figure 2. Latency from time of injection to different seizure stages induced by PTZ in wildtype and SST receptor knock-out mice. Error bars indicate SEM. Asterisk indicates significant difference from wild-type mice. For a description of seizures stages, see Materials and Methods.

and $S S T_{2}$ knock-out mice in the proportion that progressed to stage 3 and 4 seizures ( $p>0.05$ ), although a larger proportion of $S S T_{2}$ knock-outs progressed to these stages (78 and $56 \%$ for $S S T_{2}$ knock-outs, respectively, vs 48 and 33\% for wild types) (Table 1). Also, four of $23 \mathrm{SST}_{4}$ knock-out mice progressed to status epilepticus and died during seizures $(p<0.05)$, whereas this did not occur in any of the wild-type or $S S T_{2}$ or $S S T_{3}$ knock-out mice.

We also measured the latency to reach each seizure stage (Fig. 2). $S S T_{2}, S S T_{3}$, and $S S T_{4}$ knock-out mice all had significantly shorter latencies to stage 1 and stage 2 seizures compared with wild-type mice (ANOVA, $p<0.05$ ), which had latencies almost twofold of the knock-outs. $S S T_{4}$ knock-out mice had the shortest latency of all of the knock-out strains to both stage 1 and stage 2 seizures. For stage 3, only $S S T_{4}$ knock-out mice showed significantly shorter latencies compared with wild-type controls $(p<$ 0.05). $S S T_{2}$ and $S S T_{3}$ knock-out mice failed to show significant difference in latency to stage 3 , although they had a trend toward shorter latencies $(p>0.05)$. There were no significant difference among all strains for the latency to stage $4(p>0.05)$. However, this comparison is confounded by the caveat that, as previously noted, only $33 \%$ of wild-type mice entered stage 4 seizures, whereas a much higher proportion of the SST receptor knock-out mice reached this seizure stage (Table 1). Thus, these wild-type mice may represent a particularly vulnerable subpopulation.

\section{$S S T_{4}$ knock-out mice developed more severe seizures in the kainate model}

For kainate-induced seizures, a similar number of animals from wild-type mice $(n=9)$ and $S S T_{2}$ knock-out mice $(n=8)$ reached each seizure stage, with no significant difference detected between groups $\left(\chi^{2}, p>0.05\right)$ (Table 2$)$. The latencies to each seizure stage were also not significantly different between wildtypes and $S S T_{2}$ knock-outs $(p<0.05)$ (Fig. 3A).
Table 2. Comparison of wild-type and $\mathrm{SST}_{2}$ knock-out mice in proportion reaching each seizure stage after kainate treatment

\begin{tabular}{lcc}
\hline & Wild type & $\mathrm{SST}_{2}$ KO \\
\hline Stage 1 & $100 \%$ & $100 \%$ \\
Stage 2 & $67 \%$ & $88 \%$ \\
Stage 3 & $67 \%$ & $100 \%$ \\
Stage 4 & $33 \%$ & $0 \%$ \\
Stage 5 & $78 \%$ & $50 \%$ \\
Death & $0 \%$ & $0 \%$ \\
\hline
\end{tabular}

No significant difference was observed between wild type and $S S_{2}$ knock-outs for any of the seizure stages $\left(\chi^{2}\right)$.
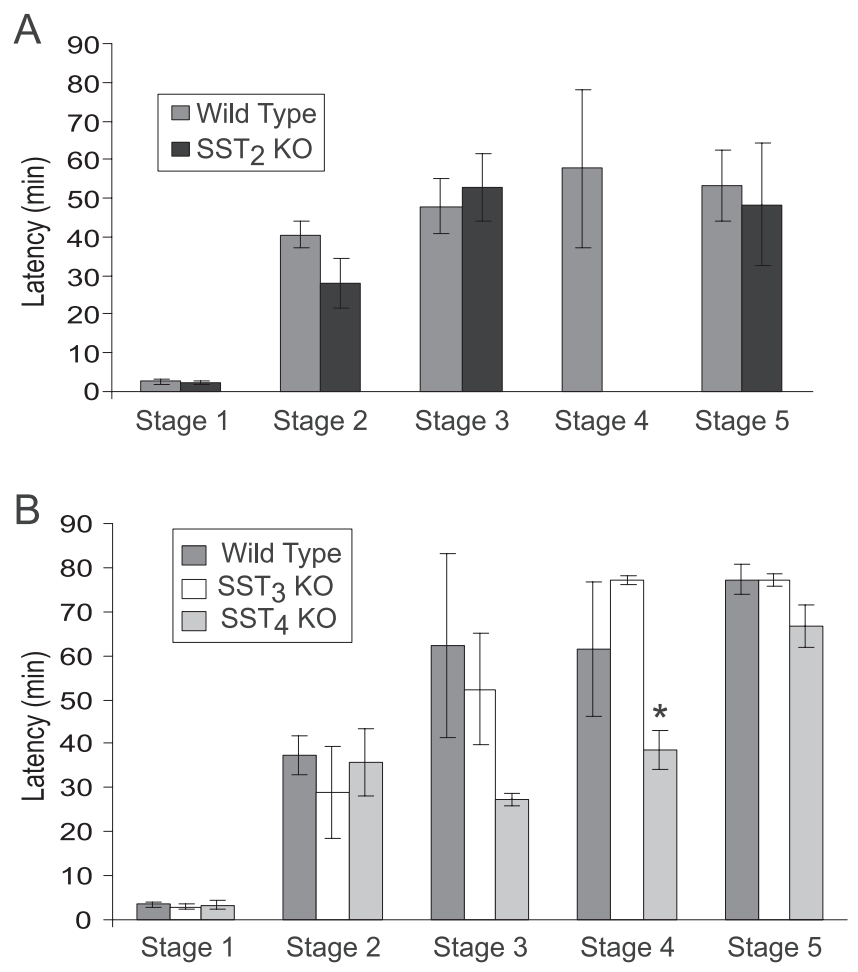

Figure 3. Latency from time of kainate injection to different seizure stages in wild-type and SST receptor knock-out mice. $A$, Comparison of wild-type and SST 2 knock-out mice. $\boldsymbol{B}$, Latency to kainate-induced seizure stages in wild-type and $S S T_{3}$ and $S S T_{4}$ knock-out mice. Error bars indicate SEM. Asterisk indicates significant difference from wild-type mice.

Table 3. Proportion of wild types and $\mathrm{SST}_{3}$ and $\mathrm{SST}_{4}$ knock-outs reaching each seizure stage after kainate treatment

\begin{tabular}{lccc}
\hline & Wild type & SST $_{3}$ KO & SST $_{4}$ KO \\
\hline Stage 1 & $100 \%$ & $100 \%$ & $100 \%$ \\
Stage 2 & $82 \%$ & $50 \%$ & $56 \%$ \\
Stage 3 & $27 \%$ & $50 \%$ & $22 \%$ \\
Stage 4 & $27 \%$ & $25 \%$ & $78 \% *$ \\
Stage 5 & $18 \%$ & $0 \%$ & $56 \%$ \\
Death & $0 \%$ & $33 \% *$ \\
\hline
\end{tabular}

No significant differences were observed in the proportion of $\mathrm{SST}_{3}$ knock-out mice that reached each seizure stage compared with wild-type mice. For $\mathrm{SST}_{4}$ knock-out mice, a greater proportion reached stage 4 seizures than wildtype mice. In addition, seizure-induced mortality was observed in a significantly greater proportion of $S_{S T} T_{4}$ knockouts than wild-type mice.

$\mathrm{SST}_{4}$ knock-out mice developed more severe seizures with kainate induction (Table 3), similar to our findings in the PTZ model. The majority of $S_{S} T_{4}$ knock-out mice (seven of nine) exhibited stage 4 seizures, compared with only 3 of 11 wild-type and 2 of $8 S_{S T}$ knock-out mice. The difference between $S_{3} T_{4}$ and wild type was significant $(p<0.05)$. In addition, the mortality rate was significantly higher in $S_{S} T_{4}$ knock-out group than that in 

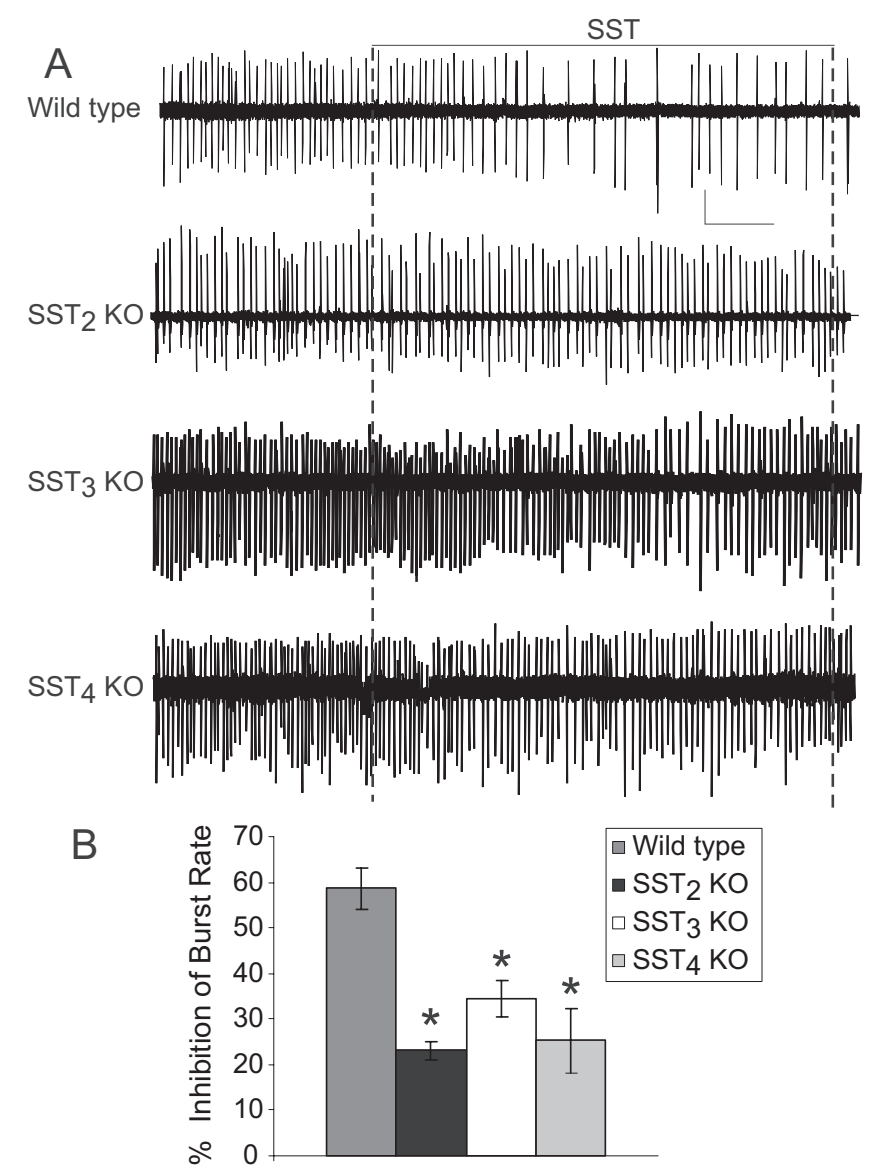

Figure 4. Inhibition of epileptiform bursting in CA1 of SST receptor knock-out mice. A, Representative voltage recordings for each strain. Calibration: wild type, $\mathrm{SST}_{2} \mathrm{KO}, 0.25 \mathrm{mV} ; \mathrm{SST}_{3}$ and $\mathrm{SST}_{4}$ wild type, $0.2 \mathrm{mV} ; 1 \mathrm{~min}$. $\boldsymbol{B}$, Mean inhibition of epileptiform burst rate by $1 \mu \mathrm{m} S \mathrm{ST}$ for each mouse strain. Asterisks indicate a significant difference from wild-type mice.

wild-type and $S T_{3}$ knock-out groups $(p<0.05)$. Three of nine $\mathrm{SST}_{4}$ knock-out mice died during the seizure episode, whereas none from other groups died. Unlike in the PTZ model, $S S T_{3}$ knock-out mice did not develop more severe seizures than wildtype controls (Table 3 ).

When latencies were measured, $S S T_{3}$ knock-outs were found to have a similar latency to reach each seizures stage as wild-type mice. $S_{S T}$ knock-outs, however, had a significantly shorter latency to reach stage 4 compared with wild-type controls (Fig. $3 B$ ) (ANOVA, $p<0.05$ ). There was no difference between $S S T_{4}$ knock-outs and wild-type mice in latencies to any of the other seizure stages (Fig. $3 B)(p>0.05)$.

\section{SST had diminished effect on inhibition of spontaneous} epileptiform bursting in CA1 of SST receptor knock-out mice In extracellular recordings from CA1 in hippocampal slices, there was no significant difference of bursting frequencies among wildtype and knock-out mice (data not shown). In wild-type slices $(n=11), 1 \mu \mathrm{M}$ SST (a maximal concentration) (data not shown) decreased bursting frequency from $0.38 \pm 0.07$ to $0.16 \pm 0.04$ $(58 \pm 4.6 \%$ inhibition). However, this same concentration of SST had a significantly reduced effect in SST knock-out mice (Fig. 4) (ANOVA, $p<0.05$ ). Inhibition by SST was $23 \%$ in slices from $S S T_{2}$ knock-out mice $(n=7), 34 \%$ in $S S T_{3}$ knock-out mice $(n=$ 9 ), and $25 \%$ in $S S T_{4}$ knock-out mice $(n=8)$, respectively $(p<$ 0.05 for control vs SST in all three knock-out strains, paired $t$
Table 4. Inhibition of bursting by subtype-selective ligands

\begin{tabular}{llcc}
\hline Ligand & Receptor(s) activated & \% inhibition of burst rate & Number of slices \\
\hline SST & All & $58.6 \pm 4 \%$ & 11 \\
Octreotide & SST $_{2}>$ SST $_{3}$ & $33.9 \pm 4 \%^{*}$ & 9 \\
L-796,778 & SST $_{3}$ & $5.2 \pm 3.4^{*, * *}$ & 5 \\
J-2156 & SST $_{4}$ & $21.8 \pm 3 \%^{*}$ & 10 \\
L-803,087 & SST $_{4}$ & $2.1 \pm 5.7 \%^{*, * *}$ & 8 \\
Octreotide + J-2156 & SST $_{2}+$ SST $_{4}$ & $47.0 \pm 5$ & 6 \\
SST + SRA880 & All but SST $_{1}$ & $47.0 \pm 2$ & 7 \\
SST + ACQ090 & All but SST & $46 \pm 5$ & 6
\end{tabular}

Concentration is $1 \mu \mathrm{m}$ for all drugs except when octreotide and J-2156 are coapplied (0.5 $\mu \mathrm{m}$ each).

${ }^{a} S_{S T} T_{1}$-selective antagonist.

${ }^{b} \mathrm{SST}_{3}$-selective antagonist.

*Significantly different from SST alone ( $p<0.05$; unpaired $t$ test) ; ${ }^{*}$ no significant inhibition of burst rate ( $p>$ 0.05 ; paired $t$ test).

test). In CA1 of slices from $S S T_{2} / S S T_{4}$ double knock-outs, SST did not inhibit epileptiform bursting ( $105 \pm 2 \%$ of control burst rate; $n=7, p>0.05)$.

\section{Pharmacological validation of receptor knock-out studies}

We used SST receptor agonists or antagonists to determine the inhibitory effect of individual receptor subtypes in wild-type mice and to validate the results from knock-out mice. Octreotide is the most commonly used $\mathrm{SST}_{2}$ agonist (Vezzani et al., 1991; Hoyer et al., 1995; Perez et al., 1995; Schoeffter et al., 1995; Hicks et al., 1998). Application of $1 \mu \mathrm{M}$ octreotide resulted in $33.9 \%$ inhibition of epileptiform bursting in CA1 of wild-type mice ( $\mathrm{Ta}$ ble. 4$)$, and a reduced but significant $(12 \pm 2 \%)$ inhibition in $S S T_{2}$ knock-out mice ( $\left.p<0.05 ; n=5\right)$. J-2156 is a newly available high affinity nonpeptide $\mathrm{SST}_{4}$ agonist (Engstrom et al., 2006). Superfusion of $1 \mu \mathrm{M} \mathrm{J}-2156$ resulted in a $21.8 \pm 3 \%$ inhibition of bursting in wild-type mice $(p<0.05)$ (Table 4$)$ and had no effect on $S_{S T}$ knock-out mice $(p>0.05 ; n=5)$. Another $\mathrm{SST}_{4}$-selective nonpeptide agonist, $\mathrm{L}-803,087(1 \mu \mathrm{M})$, did not significantly reduce epileptiform burst rate in wild-type mice (Table 4).

The $\mathrm{SST}_{3}$-selective nonpeptide agonist L-769,778 (Rohrer et al., 1998) did not modulate epileptiform bursting in CA1 of wildtype slices at $1 \mu \mathrm{M}(p>0.05 ; n=5)$ (Table 4$)$. At $10 \mu \mathrm{M}$ concentration, L-796,778 irreversibly increased burst rate in two slices while having no effect in the other two $(120 \pm 28 \%$ of control, $n=4, p>0.05)$. We also examined the effect of a selective $\mathrm{SST}_{3}$ antagonist, ACQ090, in wild-type mice. ACQ090 (1 $\mu \mathrm{M})$ was applied $15 \mathrm{~min}$ before application of $1 \mu \mathrm{M}$ SST. ACQ090 alone significantly increased burst rate by $18 \%(p<0.05)$, but inhibition by exogenous SST in the presence of ACQ090 was not significantly different from SST alone $(p>0.05 ; n=6)$ (Table 4$)$.

We also coapplied octreotide and J-2156 together to determine whether activation of both $\mathrm{SST}_{2}$ and $\mathrm{SST}_{4}$ resulted in a similar degree of inhibition as SST. We found that $0.5 \mu \mathrm{M}$ octreotide and $0.5 \mu \mathrm{M} \mathrm{J}-2156$ together reduced epileptiform bursting by $47 \pm 5 \%(n=6)$. This was not significantly different from $1 \mu \mathrm{M}$ SST $(p>0.05)$.

Because SST $_{1}$ has been suggested previously to contribute to inhibition of bursting by SST in mouse hippocampus (Cammalleri et al., 2004), we also examined whether a SST ${ }_{1}$-selective antagonist could affect the inhibitory action of SST. When applied alone, the $\mathrm{SST}_{1}$ antagonist SRA-880 $(1 \mu \mathrm{M})$ modestly increased burst rate $(112 \pm 2 \%$ of control; $n=7)$. However, SST inhibition of epileptiform bursting was not affected by coapplication of SRA-880 (47 $\pm 2 \%$ inhibition), indicating that $\mathrm{SST}_{1}$ does not play a major role in regulating epileptiform bursting in CA1. 
Contribution of $\mathrm{K}^{+} \mathrm{M}$-current to inhibition of epileptiform bursting by SST

A major mechanism of action of SST in CA1 is an increase in the $\mathrm{K}^{+}$M-current $\left(I_{\mathrm{M}}\right)$ (Moore et al., 1988; Schweitzer et al., 1990), a voltage sensitive $\mathrm{K}^{+}$current important in regulating epileptiform activity in hippocampus (Qiu et al., 2007). To determine the contribution of $I_{\mathrm{M}}$ in SST inhibition of epileptiform bursting, we blocked the current using the selective M-channel blocker linopirdine. As we have reported previously for rat hippocampus (Qiu et al., 2007), after $I_{\mathrm{M}}$ blockade, the duration of the interictal bursts increase. The effect of linopirdine on burst duration was not significantly different between wild type (216 $\pm 12 \%$ of control), SST 2 (230 $\pm 51 \%)$, and $S_{S T}$ knock-outs (225 $\left.\pm 32 \%\right)$. In wild-type mice, when linopirdine $(20 \mu \mathrm{M})$ was superfused beginning 20 min earlier, $1 \mu \mathrm{M}$ SST reduced epileptiform bursting by $28 \pm 3 \%(n=9)$, compared with $58 \pm 5 \%$ inhibition by SST alone (Fig. 5). Thus, with $I_{\mathrm{M}}$ blocked, SST efficacy in inhibiting epileptiform bursting is reduced by $\sim 50 \%$. We did similar experiments in $S S T_{2}$ and $S S T_{4}$ knock-out mice. In $S S T_{2}$ knock-out mice, linopirdine completely prevents inhibition of bursting by SST $(4.2 \pm 3.6 \%)$, compared with $23 \pm 4 \%$ for SST alone in slices from the same mice (Fig. 5) $(n=6)$. In slices from $S_{S T}$ knockout mice, no significant difference was found in SST inhibition of epileptiform burst rate in the presence of linopirdine $(27 \pm 1 \%$; $n=5)$ when compared with SST alone $(23 \pm 5 \% ; n=7)$. These results suggest that the major inhibitory SST receptor remaining in $S S T_{2}$ knock-out mice, likely $S S T_{4}$, mediates its action by increasing $I_{\mathrm{M}}$. However, the major SST receptor remaining in $S S T_{4}$ knock-out mice, likely $\mathrm{SST}_{2}$, does not appear to act via $I_{\mathrm{M}}$ in mediating the inhibitory effects of SST on epileptiform bursting.

\section{$\mathrm{SST}_{4}$ mediates SST-induced increase in $\mathrm{I}_{\mathrm{M}}$}

To directly assess coupling of $\mathrm{SST}_{2}$ and $\mathrm{SST}_{4}$ to $I_{\mathrm{M}}$, we did voltageclamp studies in wild-type and knock-out mice using sharp intracellular electrodes. Resting membrane potential (RMP) and input resistance $\left(R_{\text {in }}\right)$ were not different between wild type (RMP, $\left.-66 \pm 1.2 \mathrm{mV} ; R_{\text {in }}, 86 \pm 4.9 \mathrm{M} \Omega\right), S S T_{2}(-66 \pm 1.0 \mathrm{mV} ; 74 \pm 3.8$ $\mathrm{M} \Omega$, and $S S T_{4}$ knock-outs ( $-67 \pm 1.0 \mathrm{mV} ; 77 \pm 0.7 .0 \mathrm{M} \Omega$ ). Control $I_{\mathrm{M}}$ amplitudes measured from a holding potential of $-40 \mathrm{mV}$ with a step to $-60 \mathrm{mV}$ were similar to a previous report on C57BL/6J mice (Otto et al., 2006). We did not observe a significant difference in amplitudes between wild-type $(57 \pm 12$ $\mathrm{pA}), S S T_{2}(77 \pm 10 \mathrm{pA})$, and $S S T_{4}$ knock-out mice (56 $\pm 6 \mathrm{pA}$; one-way ANOVA, $p>0.05)$. The kinetics of deactivation $(\tau)$ measured with the same step protocol were also not significantly different between wild-type (162 $\pm 30 \mathrm{~ms}), S S T_{2}(139 \pm 42 \mathrm{~ms})$, and $S S T_{4}$ knock-outs ( $139 \pm 22 \mathrm{~ms}$; one-way ANOVA, $\left.p>0.05\right)$ and were also comparable with the previous report in C57BL/6J mice (Otto et al., 2006).

We examined whether SST augmented $I_{\mathrm{M}}$ on mouse hippocampus, as has been reported in rat (Moore et al., 1988). Superfusion of $1 \mu \mathrm{M}$ SST increased $I_{\mathrm{M}}$ measured using hyperpolarizing voltage steps from a holding potential near $-40 \mathrm{mV}$ (Fig. $6 A, B)$. The SST-induced increase at voltage steps to $-60 \mathrm{mV}$ measured $128 \pm 20 \mathrm{pA}$. This SST effect is similar in magnitude to that reported in rat (Schweitzer et al., 1993; Moore et al., 1994). SST also increased the holding current at $-40 \mathrm{mV}$ by $190 \mathrm{pA}$.

We next examined SST actions on $I_{\mathrm{M}}$ in $S S T_{2}$ and $S S T_{4}$ knockout mice. SST $(1 \mu \mathrm{M})$ significantly enhanced $I_{\mathrm{M}}$ amplitude at each individual command step in $S S T_{2}$ knock-out mice $(p<0.05)$ (Fig. 6A,B). There was no significant difference in the SST effect between wild type and $S S T_{2}$ knock-outs (ANOVA, $p<0.05$ ). SST increased the holding current at $-40 \mathrm{mV}$ by $216 \mathrm{pA}$, which was
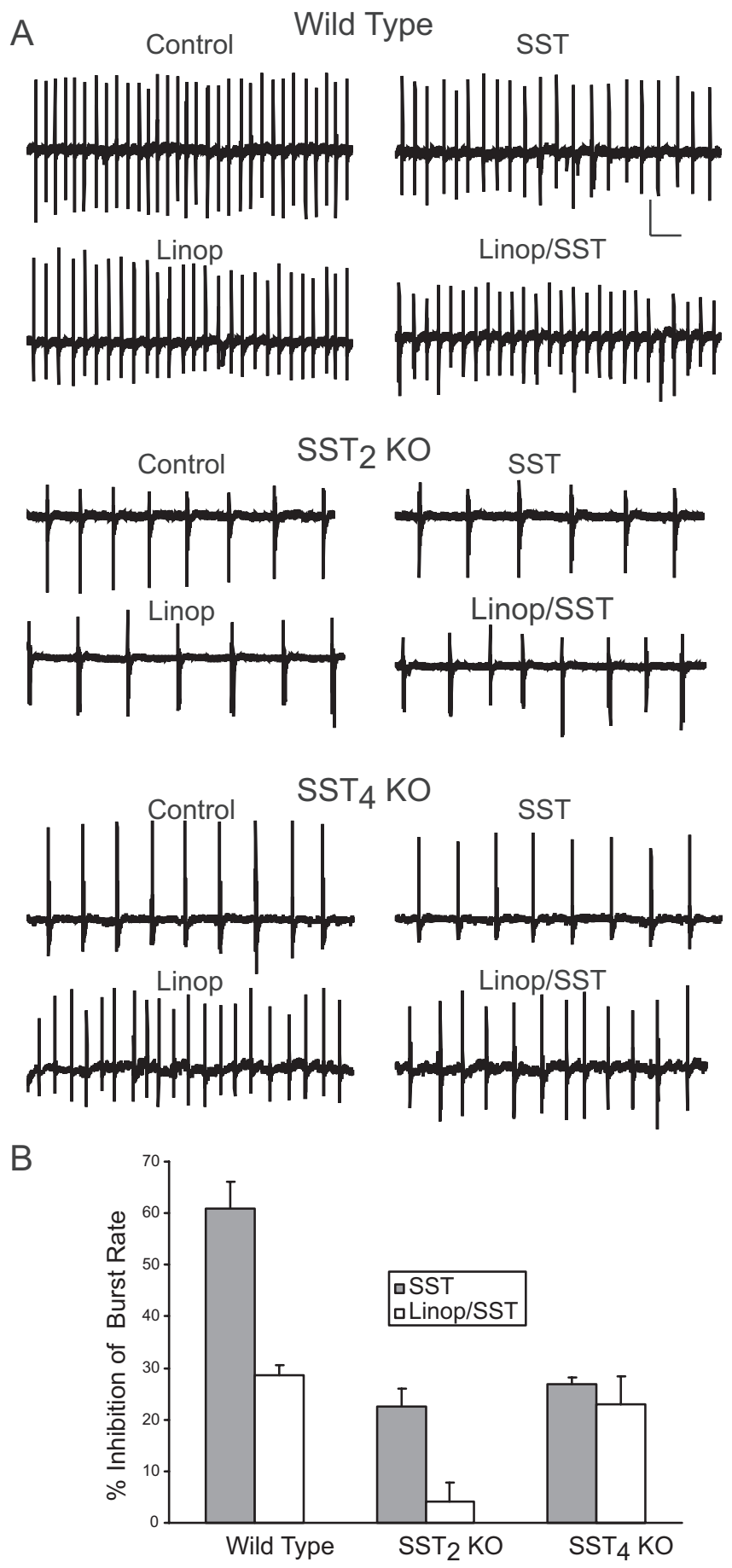

Figure 5. Contribution of $I_{M}$ to SST mediated inhibition of epileptiform bursting. $\boldsymbol{A}$, Representative traces showing SST inhibition of bursting when $I_{M}$ is blocked with linopirdine (Linop) in wild-type and SST 2 and $S S T_{4}$ knock-out mice. In wild-type and $S S T_{4}$ knock-out mice, SST inhibits burst rate to a similar degree, but no inhibition is present in $S S T_{2}$ knock-out mice. Experiments with and without linopirdine were done in different slices to avoid confounds caused by repeated applications of SST. Calibration: $0.5 \mathrm{mV}, 10 \mathrm{~s}$. B. Averaged data from the different mouse strains showing inhibition of epileptiform burst rate with and without linopirdine. With $I_{M}$ blocked, SST inhibition is partially inhibited in wild-type mice, absent in SST 2 knock-outs, and unaffected in $S_{S} T_{4}$ knock-outs.

not significantly different from wild-type mice. In contrast to wild-type and $S S T_{2}$ knock-out mice, application of $1 \mu \mathrm{M}$ SST in $\mathrm{SST}_{4}$ knock-out mice did not significantly increase $I_{\mathrm{M}}$ recorded from CA1 pyramidal neurons $(p>0.05)$ (Fig. $6 B)$. There was a 
A

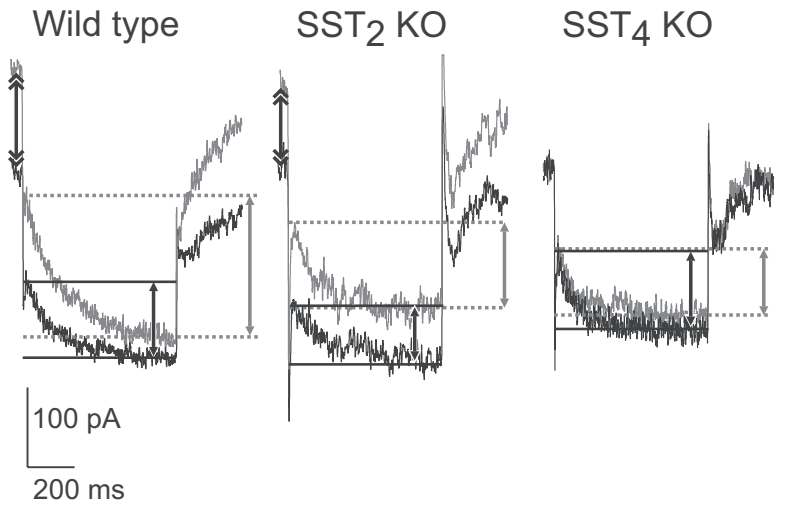

B

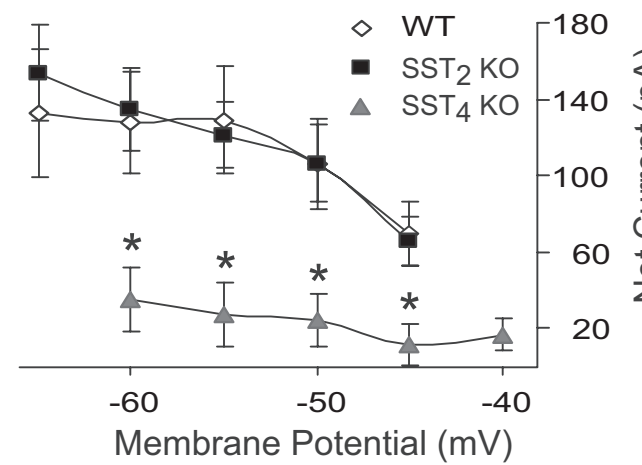

Figure 6. $\mathrm{SST}_{4}$ mediates $\mathrm{SST}$ increase in M-current. $A$, Representative current traces from CA1 hippocampal neurons of wild-type, $S S_{2}$ and $S_{S} T_{4}$ knock-out mice evoked by stepping from a holding voltage of -40 to $-60 \mathrm{mV}$ for $1 \mathrm{~s}$. Note the increase in outward holding current (double arrows) and the inward "relaxation" (single arrows) in the presence of $1 \mu \mathrm{M}$ SST (gray traces) in wild type and $S S T_{2}$ knock-outs, but not $S_{S} T_{4}$ knock-outs. $\boldsymbol{B}$, Summary of currentvoltage data for SST-induced current in CA1 neurons from wild-type and SST ${ }_{2}$ and $S S T_{4}$ knockout mice. Neurons were held at approximately $-40 \mathrm{mV}$ and $5-10 \mathrm{mV}$ hyperpolarizing voltage steps given. Currents in presence of $1 \mu \mathrm{m}$ SST were subtracted from control currents to obtain the net SST-induced current. Net SST current is similar in wild type and SST 2 knock-outs, whereas in $\mathrm{SST}_{4}$ knock-outs SST-induced current is mostly absent. Error bars indicate SEM. Asterisk indicates significant difference from wild type.

significant difference in the SST effect on $I_{M}$ between wild type and $S_{S T}$ knock-outs $(p<0.05)$. For example, with a voltage step to $-60 \mathrm{mV}$, the net increase of $I_{\mathrm{M}}$ by SST was $128 \pm 20 \mathrm{pA}$ in wild-type controls, $135 \pm 23 \mathrm{pA}$ in $S S T_{2}$ knock-out mice, and $35 \pm 8 \mathrm{pA}$ in $\mathrm{SST}_{4}$ knock-out mice (Fig. $6 \mathrm{~B}$ ). SST also did not affect the holding current recorded at $-40 \mathrm{mV}$ in $\mathrm{SST}_{4}$ knockouts $(-36 \pm 44 \mathrm{pA})$.

\section{SST does not decrease EPSCs in pyramidal neurons of mouse CA1}

SST inhibition of EPSCs in rat has been reported to be mediated by $\mathrm{SST}_{2}$ (Boehm and Betz, 1997). We explored whether this mechanism could be involved in $\mathrm{SST}_{2}$-mediated inhibitory effects in mice. We examined the action of SST on EPSCs recorded in wild-type mouse CA1 pyramidal neurons using whole-cell patch clamp and evoked by stimulating Schaeffer collaterals. After addition of $1 \mu \mathrm{M}$ SST, mean EPSC amplitude remained $95 \pm$ $5 \%$ of control (Fig. $7 A)(n=8 ; p>0.05)$. We verified SST effects in rat CA1 neurons $(n=4)$, and found that $1 \mu \mathrm{M}$ SST decreased EPSCs to $66 \pm 3 \%$ of control (Fig. $6 B)(p<0.05)$, similar to our previous report (Tallent and Siggins, 1997). Thus, unlike in rat, SST does not reduce EPSC amplitude in mouse CA1 pyramidal
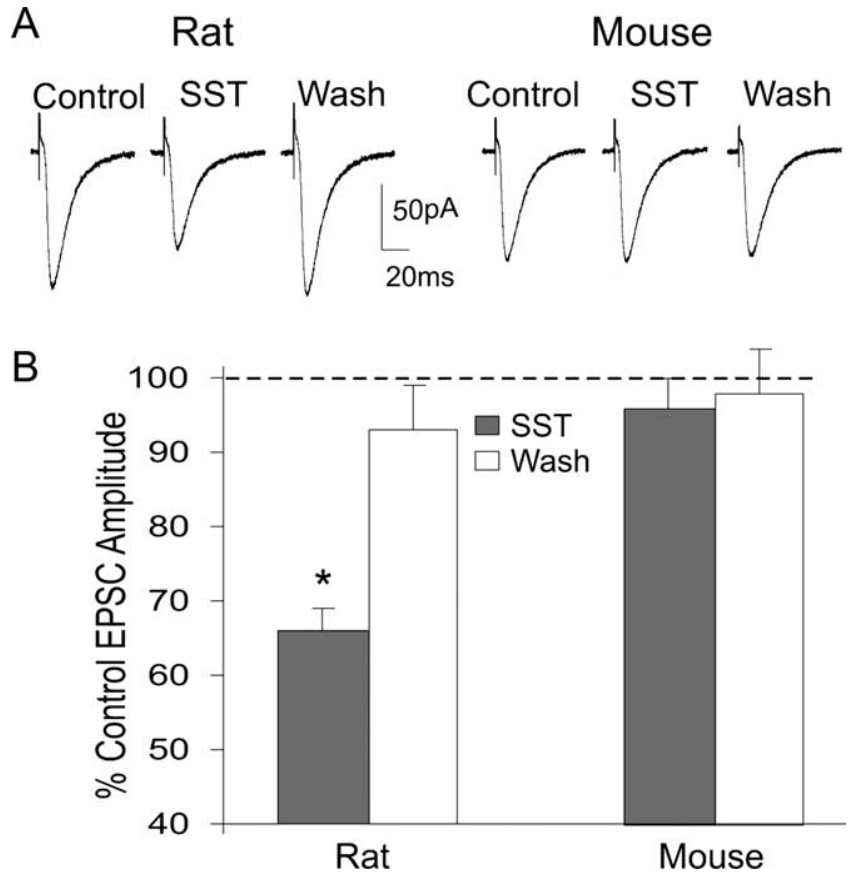

Figure 7. SST does not affect CA1 EPSCs in mice. $\boldsymbol{A}$, Representative EPSCs generated by stimulating Schaeffer collaterals and recorded using whole-cell patch clamp. SST (1 $\mu \mathrm{M})$ inhibits EPSC in recordings from rat (left), but not mice (right). $B$, Graph showing mean SST inhibition of CA1 EPSC amplitude in rats and mice. In rats but not mice, SST (1 $\mu \mathrm{m})$ significantly reduced EPSC amplitude. Error bars indicate SEM. Asterisk indicates significant difference from control.

neurons, indicating this mechanism does not account for $\mathrm{SST}_{2}$ mediated inhibition of epileptiform bursting.

\section{Discussion}

Our results demonstrate a major role for $\mathrm{SST}_{4}$ receptors in SST function in hippocampus. Interestingly, in all three of the SST receptor knock-out mice studied, $S S T_{2}, S S T_{3}$, and $S S T_{4}$, we observed a decreased latency to stage 1 and stage 2 seizures in the PTZ model. Stage 3 and stage 4 seizures also occurred significantly more in $S S T_{3}$ and $S S T_{4}$ knock-out mice, but not in $S S T_{2}$ knock-out mice. $S_{S T}$ knock-outs showed the most robust response to PTZ, and were the only strain where seizure-induced death occasionally occurred. In wild-type animals, PTZ is considered a rather mild chemoconvulsant with little or no mortality observed in most studies (Sarkisian, 2001).

We used a second seizure model, subcutaneous injection of kainate, to confirm the importance of $\mathrm{SST}_{4}$ in seizure modulation. $S S T_{2}$ and $S S T_{3}$ knock-outs did not exhibit more severe seizures in this model. A previous study using intrahippocampal kainate injections showed a decreased vulnerability to seizures in $S S T_{2}$ knock-outs (Moneta et al., 2002), but we did not observe this with systemic IP injections. $S S T_{4}$ knock-outs exhibited both a significantly higher proportion and a shorter latency to stage 4 seizures in the kainate model than wild-type mice. Thus, although the results in $S_{S} T_{4}$ knock-out mice were consistent between the two models, $S S T_{2}$ and $S S T_{3}$ knock-outs demonstrated increased seizure susceptibility only in the PTZ model. This could reflect the different mechanism of seizure generation by these two drugs, because PTZ is a GABA receptor blocker whereas kainate activates glutamate receptors. These discrepancies could also be related to differences in seizure types generated by the two chemoconvulsants. PTZ induces generalized cortical seizures, with hippocampal involvement late (Starzl et al., 1953; Brevard et 
al., 2006). Kainate is used to model of partial seizures, with critical involvement of hippocampus from early stages (Sarkisian, 2001). Thus, the increased vulnerability in $S S T_{4}$ knock-outs to kainateinduced seizure could reflect its relative importance in controlling hippocampal excitability compared with $S S T_{2}$ and $S S T_{3}$. This agrees with anatomical studies showing that $\mathrm{SST}_{4}$ is the predominate SST receptor in CA1 hippocampus (Videau et al., 2003).

Both $\mathrm{SST}_{2}$ and $\mathrm{SST}_{4}$ contribute to SST inhibition of bursting in CA1 in hippocampal slices. SST actions on CA1 bursting are attenuated to a similar degree in $\mathrm{SST}_{2}$ and $\mathrm{SST}_{4}$ knock-outs, and no SST inhibition of epileptiform bursting remains in the $S S T_{2} /$ $\mathrm{SST}_{4}$ double knock-out. We confirmed these findings with pharmacological studies in wild-type mice, suggesting that functionally these knock-out mice have few compensatory changes in expression of the remaining receptors. We demonstrate that $\mathrm{SST}_{2}$ and $\mathrm{SST}_{4}$-selective ligands inhibit bursting to a lesser degree than SST itself. With coapplication, the degree of inhibition by $\mathrm{SST}_{2}$ and $\mathrm{SST}_{4}$ agonists is similar to SST. Thus, the majority of SST inhibition of epileptiform bursting in CA1 is mediated by $\mathrm{SST}_{2}$ and $\mathrm{SST}_{4}$. A previous study suggested that $\mathrm{SST}_{1}$ can mediate SST inhibition of bursting in hippocampal slices (Cammalleri et al., 2004); however, the SST 1 antagonist used in previous work, SRA880 , did not attenuate SST-mediated inhibition of bursting in our model.

The role of $\mathrm{SST}_{3}$ in hippocampus is less clear. $\mathrm{SST}_{3}$ knock-out mice had shorter latencies to stage 1 and stage 2 seizures induced by PTZ, and a reduced response to SST in CA1 in vitro. These results suggest that $\mathrm{SST}_{3}$ may contribute to the antiepileptic actions of SST. However, unlike with the $S S T_{2}$ and $S S T_{4}$ knockouts, we were unable to confirm these findings pharmacologically. The $\mathrm{SST}_{3}$-selective agonist did not regulate epileptiform bursting in wild-type mice, nor did the $\mathrm{SST}_{3}$ antagonist reduce inhibition of bursting by SST. Because testing of these $\mathrm{SST}_{3}$ ligands in situ has been limited, one explanation is that these compounds do not appropriately interact with $\mathrm{SST}_{3}$ in our hippocampal slice preparation, as seems to be the case with the $\mathrm{SST}_{4}$ agonist L-803,087. However, additional data support the conclusion that $\mathrm{SST}_{3}$ does not mediate acute electrophysiological actions of SST. As discussed above, SST does not inhibit bursting in the $S_{S T} T_{2} / S S T_{4}$ double knock-out, and coapplication of $\mathrm{SST}_{2}$ and $\mathrm{SST}_{4}$ agonists largely recapitulates the SST effect. Thus, the preponderance of evidence suggests that $\mathrm{SST}_{3}$ does not contribute to acute electrophysiological actions of SST in hippocampus. $\mathrm{SST}_{3}$ is located on neuronal cilia that are believed to be involved in neuronal signaling (Fuchs and Schwark, 2004). SST ${ }_{3}$ could therefore modulate hippocampal excitability by regulating signaling pathways.

SST modulation of $I_{M}$ in rat CA1 neurons has been well characterized (Moore et al., 1988; Schweitzer et al., 1990, 1993). We demonstrate here that SST likewise augments $I_{\mathrm{M}}$ in mouse CA1 neurons. This action of SST is absent in $S S T_{4}$ knock-out mice, suggesting that this receptor is critical in coupling to $I_{\mathrm{M}}$. SST mediated increase in $I_{\mathrm{M}}$ is intact in $S S T_{2}$ knock-outs, indicating $\mathrm{SST}_{2}$ does not couple to this channel.

Mutations in M-channel subunits underlie a human epilepsy, benign familial neonatal convulsions (Biervert et al., 1998; Charlier et al., 1998; Singh et al., 1998), and we showed previously that $I_{\mathrm{M}}$ is critical in preventing generation of ictal events in hippocampus in both immature and adult rats (Qiu et al., 2007). Retigabine, a drug that directly augments M-channels, reduces epileptiform activity in several in vitro hippocampal models (Armand et al., 2000; Dost and Rundfeldt, 2000), and is in clinical trials for use in epilepsy (Porter et al., 2007b). After $I_{M}$ blockade, SST inhibition of bursting is reduced by $\sim 50 \%$. In $S S T_{2}$ knock-outs, where the major SST receptor mediating SST inhibition of bursting would be $\mathrm{SST}_{4}, I_{\mathrm{M}}$ blockade prevents inhibition of epileptiform bursting by SST. In contrast, $I_{\mathrm{M}}$ blockade does not alter SST inhibition of bursting in $S_{S T}$ knock-outs, where $\mathrm{SST}_{2}$ likely mediates the majority of SST actions. These results suggest that the major mechanism through which $\mathrm{SST}_{4}$ inhibits epileptiform activity in CA1 is by activation of $I_{\mathrm{M}}$, and that $\mathrm{SST}_{2}$-mediated inhibition of bursting is independent of $I_{\mathrm{M}}$.

Although receptor-mediated inhibition of $I_{\mathrm{M}}$ has been well studied (Delmas and Brown, 2005), mechanisms through which G-protein-coupled receptors augment $I_{\mathrm{M}}$ have not received the same focus. Previous studies suggested arachidonic acid metabolites mediate SST augmentation of $I_{\mathrm{M}}$ in hippocampal CA1 pyramidal neurons via activation of $\mathrm{PLA}_{2}$ (Schweitzer et al., 1990, 1993). Because inhibition of $I_{M}$ by muscarinic receptors has been demonstrated to be via activation of PLC (Suh and Hille, 2007), this suggests reciprocal modulation of M-channels by phospholipase pathways.

SST receptors have distinct patterns of expression on hippocampal principle neurons in rats and mice. $\mathrm{SST}_{2}$ receptors are present on soma and proximal dendrites (Dournaud et al., 1996; Allen et al., 2003). SST 4 is expressed mostly in medial and proximal dendrites of principle neurons (Schreff et al., 2000). SST 3 has a pattern of expression unique to G-protein-coupled receptors, in that it is exclusively localized on neuronal cilia (Handel et al., 1999). The function of neuronal cilia is unknown, although they have been speculated to play a role in signaling (Fuchs and Schwark, 2004; Whitfield, 2004). Thus, principle neurons of hippocampus are virtually coated with SST receptors, suggesting that SST is an important signaling molecule in this region. Interestingly, SST terminals are located at the distal dendrites of pyramidal neurons in CA1, CA3, and dentate (Freund and Buzsaki, 1996). This would suggest that SST must diffuse quite far from its release site to activate $\mathrm{SST}_{2}$ and $\mathrm{SST}_{3}$. $\mathrm{SST}_{4}$ however, is localized closer to SST terminals, and therefore would likely require smaller amounts of SST release to be activated.

Our results show that $\mathrm{SST}_{2}, \mathrm{SST}_{3}$, and $\mathrm{SST}_{4}$ all appear to regulate cortical excitability, with $\mathrm{SST}_{4}$ playing the major role in regulating seizure events. Our in vitro studies implicate $\mathrm{SST}_{2}$ and $\mathrm{SST}_{4}$ as mediating the acute electrophysiological actions of SST in $\mathrm{CA1}$ hippocampus. $\mathrm{SST}_{4}$ regulates hippocampal excitability via enhancement of $I_{\mathrm{M}}$, whereas the mechanism through which $\mathrm{SST}_{2}$ acts is unknown. In rat hippocampal neurons, inhibition of EPSCs by SST has been proposed to be mediated by SST ${ }_{2}$, because the $\mathrm{SST}_{2}$-selective ligands seglitide and octreotide can mediate this response (Boehm and Betz, 1997). However, in mice, EPSCs generated by stimulation of Schaeffer collaterals were not sensitive to SST, even though we confirmed this effect in rat slices.

Another possible mechanism through which $\mathrm{SST}_{2}$ may act is inhibition of $\mathrm{Ca}^{2+}$ channels, because SST has this action in dentate granule cells (Baratta et al., 2002). $\mathrm{Ca}^{2+}$ channels contribute to dendritic depolarization during seizure events (Traub and Wong, 1983; Traub et al., 1993). The mechanism of action of $\mathrm{SST}_{3}$ is also unclear, but may involve activation of longer-term signaling pathways because this receptor does not appear to mediate acute electrophysiological actions of SST in CA1 hippocampus.

Our results suggest that new drugs acting on $\mathrm{SST}_{4}$ could have diverse clinical applications, because $\mathrm{M}$-channels are under investigation as therapeutic target of not only epilepsy, but other conditions such as neuropathic pain (Porter et al., 2007a). Because of more restricted localization of $\mathrm{SST}_{4}$ in both brain and 
periphery (Cooper et al., 2000; Schreff et al., 2000; Porter et al., 2007a), targeting this receptor could lead to drugs with fewer unwanted side effects than direct activators of M-channels.

\section{References}

Allen JP, Hathway GJ, Clarke NJ, Jowett MI, Topps S, Kendrick KM, Humphrey PPA, Wilkinson LS, Emson PC (2003) Somatostatin receptor 2 knock-out/LacZ knockin mice show impaired motor coordination and reveal sites of somatostatin action within the striatum. Eur J Neurosci 17:1881-1895.

Armand V, Rundfeldt C, Heinemann U (1999) Effects of retigabine (D23129) on different patterns of epileptiform activity induced by 4 -aminopyridine in rat entorhinal cortex hippocampal slices. Naunyn Schmiedebergs Arch Pharmacol 359:33-39.

Armand V, Rundfeldt C, Heinemann U (2000) Effects of retigabine (D23129) on different patterns of epileptiform activity induced by low magnesium in rat entorhinal cortex hippocampal slices. Epilepsia 41:28-33.

Baratta MV, Lamp T, Tallent MK (2002) Somatostatin depresses long-term potentiation and $\mathrm{Ca}^{2+}$ signaling in mouse dentate gyrus. J Neurophysiol 88:3078-3086.

Biervert C, Schroeder BC, Kubisch C, Berkovic SF, Propping P, Jentsch TJ, Steinlein OK (1998) A potassium channel mutation in neonatal human epilepsy. Science 279:403-406.

Boehm S, Betz H (1997) Somatostatin inhibits excitatory transmission at rat hippocampal synapses via presynaptic receptors. J Neurosci 17:4066-4075.

Brevard ME, Kulkarni P, King JA, Ferris CF (2006) Imaging the neural substrates involved in the genesis of pentylenetetrazol-induced seizures. Epilepsia 47:745-754.

Cammalleri M, Cervia D, Langenegger D, Liu Y, Monte MD, Hoyer D, Bagnoli P (2004) Somatostatin receptors differentially affect spontaneous epileptiform activity in mouse hippocampal slices. Eur J Neurosci 20:2711-2721.

Charlier C, Singh NA, Ryan SG, Lewis TB, Reus BE, Leach RJ, Leppert M (1998) A pore mutation in a novel KQT-like potassium channel gene in an idiopathic epilepsy family. Nat Genet 18:53-55.

Cooper EC, Aldape KD, Abosch A, Barbaro NM, Berger MS, Peacock WS, Jan YN, Jan LY (2000) Colocalization and coassembly of two human brain M-type potassium channel subunits that are mutated in epilepsy. Proc Natl Acad Sci USA 97:4914-4919.

Delmas P, Brown DA (2005) Pathways modulating neural KCNQ/M (Kv7) potassium channels. Nat Rev Neurosci 6:850-862.

Dost R, Rundfeldt C (2000) The anticonvulsant retigabine potently suppresses epileptiform discharges in the low $\mathrm{Ca}++$ and low $\mathrm{Mg}++$ model in the hippocampal slice preparation. Epilepsy Res 38:53-66.

Dournaud P, Gu YZ, Schonbrunn A, Mazella J, Tannenbaum GS, Beaudet A (1996) Localization of the somatostatin receptor $\mathrm{SST}_{2 \mathrm{~A}}$ in rat brain using a specific anti-peptide antibody. J Neurosci 16:4468-4478.

Dutar P, Vaillend C, Viollet C, Billard JM, Potier B, Carlo AS, Ungerer A, Epelbaum J (2002) Spatial learning and synaptic hippocampal plasticity in type 2 somatostatin receptor knock-out mice. Neuroscience 112:455-466.

Engstrom M, Savola JM, Wurster S (2006) Differential efficacies of somatostatin receptor agonists for G-protein activation and desensitization of somatostatin receptor subtype 4-mediated responses. J Pharmacol Exp Ther 316:1262-1268.

Freund TF, Buzsaki G (1996) Interneurons of the hippocampus. Hippocampus 6:347-470.

Fuchs JL, Schwark HD (2004) Neuronal primary cilia: a review. Cell Biol Int 28:111-118.

Handel M, Schulz S, Stanarius A, Schreff M, Erdtmann-Vourliotis M, Schmidt H, Wolf G, Hollt V (1999) Selective targeting of somatostatin receptor 3 to neuronal cilia. Neuroscience 89:909-926.

Hervieu G, Emson PC (1998) The localization of somatostatin receptor 1 (sst1) immunoreactivity in the rat brain using an $\mathrm{N}$-terminal specific antibody. Neuroscience 85:1263-1284.

Hicks GA, Feniuk W, Humphrey PP (1998) Outward current produced by somatostatin (SRIF) in rat anterior cingulate pyramidal cells in vitro. Br J Pharmacol 124:252-258.

Hoyer D, Perez J, Schoeffter P, Langenegger D, Schuepbach E, Kaupmann K, Luebbert H, Bruns C, Reubi JC (1995) Pharmacological identity be- tween somatostatin SS-2 binding sites and SSTR-1 receptors. Eur J Pharmacol Mol Pharmacol 289:151-161.

Li E, Bestor TH, Jaenisch R (1992) Targeted mutation of the DNA methyltransferase gene results in embryonic lethality. Cell 69:915-926.

Mazarati AM, Telegdy G (1992) Effects of somatostatin and antisomatostatin serum on picrotoxin-kindled seizures. Neuropharmacology 31:793-797.

Meis S, Sosulina L, Schulz S, Hollt V, Pape HC (2005) Mechanisms of somatostatin-evoked responses in neurons of the rat lateral amygdala. Eur J Neurosci 21:755-762.

Moneta D, Richichi C, Aliprandi M, Dournaud P, Dutar P, Billard JM, Carlo AS, Viollet C, Hannon JP, Fehlmann D, Nunn C, Hoyer D, Epelbaum J, Vezzani A (2002) Somatostatin receptor subtypes 2 and 4 affect seizure susceptibility and hippocampal excitatory neurotransmission in mice. Eur J Neurosci 16:843-849.

Moore SD, Madamba SG, Joels M, Siggins GR (1988) Somatostatin augments the M-current in hippocampal neurons. Science 239:278-280.

Moore SD, Madamba SG, Schweitzer P, Siggins GR (1994) Voltagedependent effects of opioid peptides on hippocampal CA3 pyramidal neurons in vitro. J Neurosci 14:809-820.

Otto JF, Yang Y, Frankel WN, White HS, Wilcox KS (2006) A spontaneous mutation involving Kcnq2 (Kv7.2) reduces M-current density and spike frequency adaptation in mouse CA1 neurons. J Neurosci 26:2053-2059.

Perez J, Vezzani A, Civenni G, Tutka P, Rizzi M, Schuepbach E, Hoyer D (1995) Functional effects of D-Phe-c[Cys-Tyr-D-Trp-Lys-Val-Cys]Trp-NH2 and differential changes in somatostatin receptor messenger RNAs, binding sites and somatostatin release in kainic acid-treated rats. Neuroscience 65:1087-1097.

Porter RJ, Nohria V, Rundfeldt C (2007a) Retigabine. Neurotherapeutics 4:149-154.

Porter RJ, Partiot A, Sachdeo R, Nohria V, Alves WM (2007b) Randomized, multicenter, dose-ranging trial of retigabine for partial-onset seizures. Neurology 68:1197-1204.

Qiu C, Johnson BN, Tallent MK (2007) K(+) M-current regulates the transition to seizures in immature and adult hippocampus. Epilepsia 48:2047-2058.

Racine RJ (1972) Modification of seizure activity by electrical stimulation. II. Motor seizure. Electroencephalogr Clin Neurophysiol 32:281-294.

Ramirez JL, Mouchantaf R, Kumar U, Otero Corchon V, Rubinstein M, Low MJ, Patel YC (2002) Brain somatostatin receptors are up-regulated in somatostatin-deficient mice. Mol Endocrinol 16:1951-1963.

Rohrer SP, Birzin ET, Mosley RT, Berk SC, Hutchins SM, Shen DM, Xiong Y, Hayes EC, Parmar RM, Foor F, Mitra SW, Degrado SJ, Shu M, Klopp JM, Cai SJ, Blake A, Chan WW, Pasternak A, Yang L, Patchett AA, et al. (1998) Rapid identification of subtype-selective agonists of the somatostatin receptor through combinatorial chemistry. Science 282:737-740.

Sarkisian MR (2001) Overview of the current animal models for human seizure and epileptic disorders. Epilepsy Behav 2:201-216.

Schoeffter P, Perez J, Langenegger D, Schuepbach E, Bobirnac I, Luebbert H, Bruns C, Hoyer D (1995) Characterization and distribution of somatostatin SS-1 and SRIF-1 binding sites in rat brain: Identity with SSTR-2 receptors. Eur J Pharmacol Mol Pharmacol 289:163-173.

Schreff M, Schulz S, Handel M, Keilhoff G, Braun H, Pereira G, Klutzny M, Schmidt H, Wolf G, Hollt V (2000) Distribution, targeting, and internalization of the sst4 somatostatin receptor in rat brain. J Neurosci 20:3785-3797.

Schulz S, Handel M, Schreff M, Schmidt H, Hollt V (2000) Localization of five somatostatin receptors in the rat central nervous system using subtype-specific antibodies. J Physiol Paris 94:259-264.

Schwabe W, Brennan MB, Hochgeschwender U (1996) Isolation and characterization of the mouse (Mus musculus) somatostatin receptor type-4encoding gene (mSSTR4). Gene 168:233-235.

Schweitzer P, Madamba S, Siggins GR (1990) Arachidonic acid metabolites as mediators of somatostatin-induced increase of neuronal M-current. Nature 346:464-467.

Schweitzer P, Madamba S, Champagnat J, Siggins GR (1993) Somatostatin inhibition of hippocampal CA1 pyramidal neurons: mediation by arachidonic acid and its metabolites. J Neurosci 13:2033-2049.

Schweitzer P, Madamba SG, Siggins GR (1998) Somatostatin increases a voltage-insensitive $\mathrm{K}+$ conductance in rat CA1 hippocampal neurons. J Neurophysiol 79:1230-1238.

Sharifi N, Diehl N, Yaswen L, Brennan MB, Hochgeschwender U (2001) 
Generation of dynorphin knock-out mice. Brain Res Mol Brain Res $86: 70-75$.

Silva AJ, Simpson EM, Takahashi JS, Lipp H, Nakanishi S, Wehner JM, Giese KP, Tully T, Abel T, Chapman PF, Fox K, Grant S, Itohara S, Lathe R, Mayford M, McNamara JO, Morris RJ, Picciotto M, Roder M, Shin H, et al. (1997) Mutant mice and neuroscience: recommendations concerning genetic background. Banbury Conference on genetic background in mice. Neuron 19:755-759.

Singh NA, Charlier C, Stauffer D, DuPont BR, Leach RJ, Melis R, Ronen GM, Bjerre I, Quattlebaum T, Murphy JV, McHarg ML, Gagnon D, Rosales TO, Peiffer A, Anderson VE, Leppert M (1998) A novel potassium channel gene, KCNQ2, is mutated in an inherited epilepsy of newborns. Nat Genet 18:25-29.

Singh NA, Westenskow P, Charlier C, Pappas C, Leslie J, Dillon J, Anderson VE, Sanguinetti MC, Leppert MF (2003) KCNQ2 and KCNQ3 potassium channel genes in benign familial neonatal convulsions: expansion of the functional and mutation spectrum. Brain 126:2726-2737.

Starzl TE, Niemer WT, Dell M, Forgrave PR (1953) Cortical and subcortical electrical activity in experimental seizures induced by metrazol. J Neuropathol Exp Neurol 12:262-276.

Suh BC, Hille B (2007) Regulation of KCNQ channels by manipulation of phosphoinositides. J Physiol 582:911-916.

Tallent MK, Siggins GR (1997) Somatostatin depresses excitatory but not inhibitory neurotransmission in rat CA1 hippocampus. J Neurophysiol 78:3008-3018.

Tallent MK, Madamba SG, Siggins GR (2001) Nociceptin reduces epilepti- form events in CA3 hippocampus via presynaptic and postsynaptic mechanisms. J Neurosci 21:6940-6948.

Traub RD, Wong RK (1983) Synchronized burst discharge in disinhibited hippocampal slice. II. Model of cellular mechanism. J Neurophysiol 49:459-471.

Traub RD, Miles R, Jefferys JG (1993) Synaptic and intrinsic conductances shape picrotoxin-induced synchronized after-discharges in the guineapig hippocampal slice. J Physiol (Lond) 461:525-547.

Vezzani A, Hoyer D (1999) Brain somatostatin: a candidate inhibitory role in seizures and epileptogenesis. Eur J Neurosci 11:3767-3776.

Vezzani A, Serafini R, Stasi MA, Vigano G, Rizzi M, Samanin R (1991) A peptidase-resistant cyclic octapeptide analogue of somatostatin (SMS 201-995) modulates seizures induced by quinolic acid and kainic acid differently in the rat hippocampus. Neuropharmacology 30:345-352.

Videau C, Hochgeschwender U, Kreienkamp HJ, Brennan MB, Viollet C, Richter D, Epelbaum J (2003) Characterisation of [125I]-Tyr0DTrp8somatostatin binding in sst1- to sst4- and SRIF-gene-invalidated mouse brain. Naunyn Schmiedebergs Arch Pharmacol 367:562-571.

Viollet C, Vaillend C, Videau C, Bluet-Pajot MT, Ungerer A, L'Heritier A, Kopp C, Potier B, Billard J, Schaeffer J, Smith RG, Rohrer SP, Wilkinson H, Zheng H, Epelbaum J (2000) Involvement of sst2 somatostatin receptor in locomotor, exploratory activity and emotional reactivity in mice. Eur J Neurosci 12:3761-3770.

Whitfield JF (2004) The neuronal primary cilium—an extrasynaptic signaling device. Cell Signal 16:763-767.

Zeyda T, Diehl N, Paylor R, Brennan MB, Hochgeschwender U (2001) Impairment in motor learning of somatostatin null mutant mice. Brain Res 906:107-114. 